\title{
Minipuberty of human infancy - A window of opportunity to evaluate hypogonadism and differences of sex development?
}

Christoffer Højrup Renault, BSc Med, Lise Aksglaede, MD, PhD, Ditte Wøjdemann, BSc Med, Anna Berg Hansen, BSc Med, Rikke Beck Jensen, MD, PhD, Anders Juul, MD, DMSc, PhD

Department of Growth and Reproduction, Rigshospitalet, University of Copenhagen, Copenhagen, Denmark

Received: 6 May, 2020

Accepted: 20 May, 2020

Address for correspondence: Christoffer Højrup Renault, BSc Med Department of Growth and Reproduction, Section 5064, Rigshospitalet, Blegdamsvej 9, DK-2100 Copenhagen $\varnothing$, Denmark

Tel: $+45-35455064$

Fax: +45-35456054

E-mail: Christoffer.Hoejrup.Renault@ regionH.dk

https://orcid.org/0000-0003-00436819
Activation of the hypothalamic-pituitary-gonadal (HPG) axis happens in 3 phases during life. The first phase is during fetal life and is only separated from the second phase, called minipuberty, by the high concentration of placental hormones at birth. The third period of activation of the HPG axis is puberty and is well-described. Minipuberty consists of the neonatal activation of the HPG axis, mainly in the first 1-6 months, where the resulting high levels of gonadotropins and sex steroids induce the maturation of sexual organs in both sexes. With gonadal activation, testosterone levels rise in boys with peak levels after 1-3 months, which results in penile and testicular growth. In girls, gonadal activation leads to follicular maturation and a fluctuating increase in estrogen levels, with more controversy regarding the actual influence on the target tissue. The regulation of the HPG axis is complex, involving many biological and environmental factors. Only a few of these have known effects. Many details of this complex interaction of factors remain to be elucidated in order to understand the mechanisms underlying the first postnatal activation of the HPG axis as well as mechanisms shutting down the HPG axis, resulting in the hormonal quiescence observed between minipuberty and puberty. Minipuberty allows for the maturation of sexual organs and forms a platform for future fertility, but the long-term significance is still not absolutely clear. However, it provides a window of opportunity in the early detection of differences of sexual development, offering the possibility of initiating early medical treatment in some cases.

Keywords: Minipuberty, Window of opportunity, Testosterone

\section{Introduction}

The age of pubertal onset has changed markedly over time especially in girls. ${ }^{1,2)}$ Thus, we have recently demonstrated in systematic review and meta-analysis a worldwide decline in age at thelarche corresponding to 3 months per decade from 1977 to 2013 . ${ }^{3)}$ The mechanisms behind this secular trend are quite complex and multifactorial. There is a wide interindividual variation in the timing of puberty, which can be partially explained by genetic and environmental changes such as nutrition, but most parts remain unexplained. Onset of puberty is directly linked to the activation of the hypothalamic-pituitary-gonadal (HPG) hormone axis resulting in the development of secondary sexual characteristics and achievement of reproductive capacity. The pulsatile hypothalamic gonadotropin releasing hormone (GnRH) stimulates the secretion from pituitary gonadotrophs in terms of luteinizing hormone (LH) and follicle-stimulating hormone (FSH) into the bloodstream, and subsequent stimulation of gonadal hormone production. However, important developmental steps occur much earlier during the transient activation of the HPG axis already in fetal life during the second trimester 
of pregnancy ${ }^{4-8)}$ and again after birth at 1-6 months of postnatal age during the so-called minipuberty. ${ }^{8-12)}$

Minipuberty has been suggested as a critical window of programming with lifelong implications. It has been proposed that minipuberty is linked to the timing of puberty and that it may be a marker of reproductive capacity in adult life, although the physiological role and clinical importance of the elevated sex steroids during minipuberty still remain to be elucidated. We suggest that minipuberty may be used as an early "window of opportunity" to detect and even treat reproductive disorders.

\section{Sexual differentiation}

Sexual differentiation is a complex genetic and hormonal event starting in early fetal life. Until week 6 of gestation, the gonads are indifferent. Genetic sex is determined by the sex chromosome constitution (46,XX or $46, \mathrm{XY})$ and the presence or absence of the sex-determining region of the $\mathrm{Y}(S R Y)$ gene, which together with other genes determines the fate of the primitive gonad - will it differentiate into a testis or an ovary? In the presence of testes and specific testicular hormones, internal and external genitalia will follow the male pathway, whereas their absence will direct the development into the female pathway. ${ }^{13)}$

In fetal life, marked changes in the HPG-axis hormone activity occur especially in the second trimester of pregnancy, with the secretion of pituitary FSH and LH increasing already from week 10 of gestation. Peak levels of FSH and LH are seen in midgestation followed by a decrease to almost undetectable levels at term. In females, the concentration of both LH and FSH is significantly higher than in males. ${ }^{7)}$ By contrast, inhibin B secretion from gonads are significantly higher in male than in female fetuses at gestational age 26 to 28 weeks, although the levels decrease with ongoing gestation to similar levels at term. ${ }^{5}$

In the male fetus, the masculinization of genitalia and testicular descent depends on the production of testosterone and insulin-like peptide 3 (INSL3) from the Leydig cells and anti-Müllerian hormone (AMH) produced by the Sertoli cells. The Leydig cells are differentiated from testicular mesenchymal

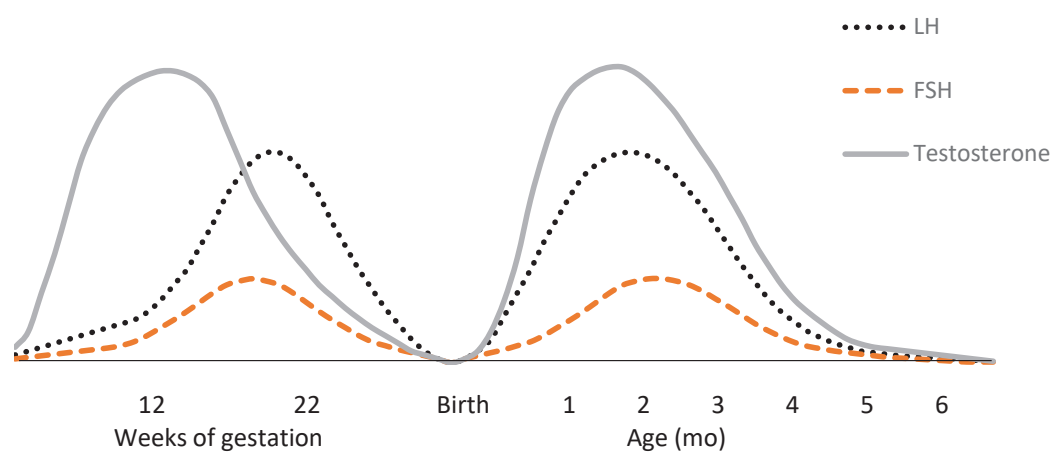

(A)

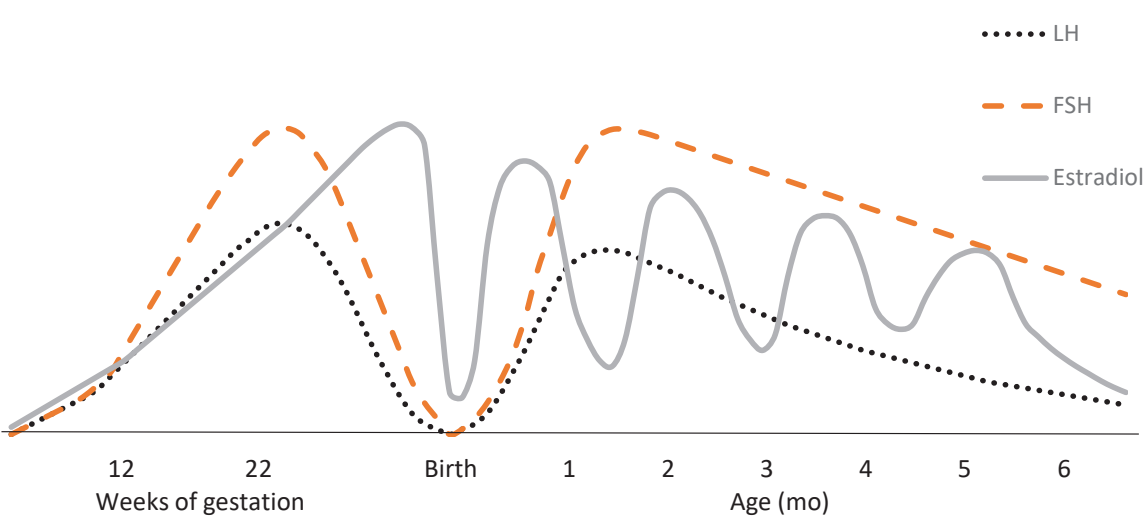

Fig. 1. (A) Male fetuses and infants. Serum LH, FSH, and testosterone concentrations throughout life in male subjects. In fetal life, placental hCG production stimulates the testosterone secretion in male fetuses during early gestation, and hereafter the fetal endogenous production of pituitary LH continues to stimulate the testosterone secretion which hereafter decreases concomitantly with FSH and LH levels towards birth. After birth $\mathrm{LH}, \mathrm{FSH}$, and testosterone increase in minipuberty with maximal levels at 1-2 months of age, followed by a significant suppression until puberty. (B) Female fetuses and infants. Serum LH, FSH, and estradiol increase in female fetuses midgestation which decreases by the end of gestation to very low levels. After birth FSH, LH, and estradiol increase at 1-2 months of age followed by slowly declining FSH, LH and fluctuating estradiol levels for 12-18 months. Females have higher FSH versus LH levels at all times compared to male fetuses and infants. LH, luteinizing hormone; FSH, follicle-stimulating hormone; hCG, human chorionic gonadotropin. Adapted from Lanciotti et al., Front Endocrinol (Lausanne) 2018;9:410. ${ }^{14)}$ 
cells with the stimulation from human chorionic gonadotropin (hCG) in the first trimester, where hCG also controls the secretion of testosterone. ${ }^{14)}$ After the 9th week of gestation, the secretion of testosterone is increasingly controlled by LH, and a clear increase in testosterone is observed. The concentration reaches its maximum between 11 and 14 weeks of gestation, with peak levels similar to adult values. Hereafter the testosterone concentration decreases towards term (Fig. 1). ${ }^{15,16)}$ During fetal life and early infancy, Sertoli cells in the male testes are immature. The immature Sertoli cells secrete AMH with the main function of triggering the involution of the Müllerian ducts in the male fetus. ${ }^{17}$

While testosterone and AMH are key to the masculinization of the male fetus, inducing the formation of male urogenital structures and involution of the Müllerian ducts, respectively, estrogen and the lack of AMH is central to the development of the female reproductive system. In the absence of AMH, the Müllerian duct develops into fallopian tubes, uterus, and the upper third of the vagina, ${ }^{18)}$ and the Wolffian ducts regress. The main source of fetal estrogen is the placenta ${ }^{8)}$ and ovarian follicles are created in the female ovaries when estrogen concentrations are high, which happens rapidly from 14 weeks of gestation and stabilizes at around week 34 . While there is a correlation between the levels of circulating estrogen and the formation of primordial follicles in the fetus, further studies are needed to interpret the roles of FSH and LH during fetal life. ${ }^{14)}$

\section{Regulation of the HPG hormone axis}

During early embryogenesis, GnRH neurons migrate from their origin in the olfactory placode to the hypothalamus and the median eminence, where $\mathrm{GnRH}$ is released into the pituitary portal vessels (for review, see ${ }^{19)}$ ). Several neurotransmitters have been identified to play a key role in regulating the $\mathrm{GnRH}$ release. Many of them derive from the same hypothalamic cell type, the KNDy neurons, which releases kisspeptin, neurokinin $\mathrm{B}(\mathrm{NKB})$, and dynorphin. Kisspeptin is a peptide, which stimulates the release of GnRH by activating the Kisspeptin receptor (KISS1R), while NKB and dynorphin participate in regulating the release of kisspeptin. ${ }^{20)}$ Studies have shown, that the inactivation of the gene encoding KISS1R results in pubertal failure. ${ }^{21,22)}$ In contrast to kisspeptin and neurokinin B, which have been identified to stimulate the activation of the HPG axis, Makorin RING-finger Protein 3 (MKRN3) has been found to act as an inhibitor. A study identified mutations causing loss of function in the MKRN3 gene to cause central precocious puberty (CPP). ${ }^{23)}$ Interestingly, MKRN3 mutations have later proven to be the most common genetic cause of familial CPP. Even though children with MKRN3 mutations are rare, such findings significantly contribute to the understanding of the central regulation of the HPG axis. MKRN3 is considered the brake on the HPG-axis, which is activated in minipuberty and released again in childhood resulting in pubertal onset. In accordance, circulating MKRN3 levels decline in boys and girls a few years before the HPG axis is reactivated in puberty. ${ }^{24,25)}$
The hypothalamic GnRH pulse generator releases GnRH pulses of 1-2 per hour into the hypophyseal portal circulation and stimulates the gonadotrophs cells in the anterior pituitary gland. This leads to the pulsatile release of gonadotropins, FSH and $\mathrm{LH}$, into the systemic bloodstream and to the target tissue in testes or ovaries.

In the testes, FSH stimulates Sertoli cells to produce inhibin $\mathrm{B}$ and $\mathrm{AMH}$, while LH stimulates Leydig cells to produce testosterone and INSL3. In the ovaries, LH stimulates theca cells to produce testosterone, which is converted into estradiol by FSH-driven aromatase activity in ovarian granulosa cells. Consequently, estradiol is released into circulation. In addition, inhibin A and B and AMH are produced in granulosa cells and released from the ovaries. ${ }^{26)}$

\section{Minipuberty in healthy infants}

In postnatal life, the HPG axis is transiently activated in the first months of life, during the minipuberty. At birth, serum concentrations of LH and FSH are low due to the suppressive effects of the high concentrations of placental hormones, ${ }^{10,12)}$ which are gradually cleared with total clearance after approximately one week. This removes the restraint, leading to elevated gonadotropin levels until 6 to 9 months of age, with the exception of FSH, which remains elevated in girls for up to 3 to 4 years. ${ }^{10,12)}$ The LH/FSH ratio increases markedly in minipuberty and clearly separates male infants from female infants. ${ }^{27}{ }^{7}$

In boys, the postnatal rise in LH and FSH is associated with increases in testosterone and INSL-3 from the Leydig cells and inhibin B and AMH from the Sertoli cells. ${ }^{28,29)}$ Similar to gonadotropin, testosterone levels are low in cord blood, but increase shortly after birth. It then reaches its peak between 1 and 3 months of age, with levels reported just beneath adult concentrations, before declining and stabilizing after approximately 4-6 months at undetectable levels (Fig. 1). 10,12) The number of Leydig cells increases concomitantly until 3 months of age when the fetal Leydig cells go into apoptosis. ${ }^{30)}$ Similarly, the Sertoli cells develop and the number of germ cells increases in the first months of age. ${ }^{31)}$ However, they do not express androgen receptors during infancy. Consequently, despite high intratesticular testosterone levels, spermatogenesis is not initiated and the production of AMH is not inhibited. Thus, the Sertoli cells produce AMH at very high concentrations during infancy, peaking at around 3 months of age, even in the presence of high levels of testosterone. ${ }^{32)}$ From the time of puberty, the main role of AMH remains to be determined. ${ }^{28)}$ At birth, circulating AMH is 35 times lower in female than in male cord blood. ${ }^{33}$ The following postnatal surge in AMH in healthy female infants correlates with the rise in the number of growing ovarian follicles. ${ }^{34)}$ This correlation is supported by the undetectable AMH levels in postmenopausal women ${ }^{35)}$ and patients with Turner syndrome, ${ }^{33)}$ and by reports of very high levels of AMH in ovarian tumors. ${ }^{36)}$

Minipuberty and the associated sex steroid levels are important for genital development in boys. Thus, penile growth is 
positively associated with testosterone levels from birth until 3 years of age with the highest growth velocity of $1 \mathrm{~mm}$ per month present during the first 3 months. ${ }^{37)}$ Likewise, minipuberty is associated with testicular growth ${ }^{38,39)}$ which is due to increased length of seminiferous tubules, total germ cell number, and Sertoli cell number, as well as decreased apoptosis of Sertoli cells (for review, see ${ }^{40)}$ ). A positive correlation between FSH levels and testicular growth has been found, with testicular volume increasing from 0.27 to $0.44 \mathrm{~cm}^{3}$ from birth until 5-6 months, and then decreasing to $0.31 \mathrm{~cm}^{3}$ at 9 months of age. ${ }^{38)}$

Genital development during minipuberty is well described in boys whereas the association between elevated reproductive hormones and the development of the female reproductive organs in minipuberty is more unclear. Estradiol levels are high in cord blood in both sexes but decrease during the following days. However, in girls, the endogenous production increases after approximately one week, corresponding with the increase in follicular development. ${ }^{41)}$ The estradiol levels then proceed to fluctuate while decreasing gradually towards the second year of life. ${ }^{42)}$ In fact, large ovarian follicles are seen more often during the first than during the second year of life. ${ }^{42,43)}$ Estradiol levels are significantly higher in the intrauterine environment, leading to the development of the uterus and mammary glands. Thus, both boys and girls have developed breast tissue at birth and later in infancy, but breast tissue grows more in girls than in boys, which is likely an effect of the estrogen surge in girls. ${ }^{44,45)}$ $\mathrm{FSH}, \mathrm{AMH}$, and breast tissue size in female minipuberty are associated with genetic variation in FSH action variants in the FSH-Receptor (FSHR) gene. ${ }^{46)}$ The length of the uterus grows until day 7 and then decreases during the first 3 months, before stabilizing in size until the second year of life. ${ }^{42)}$ This leads to controversy regarding the effect of estradiol on the uterus.

Elevated sex steroids in minipuberty may also influence other physiological endpoints such as body composition and linear growth. During the first years of life, thyroid hormones along with insulin and glucocorticoids, and hereafter growth hormone, and insulin-like growth factors influence linear growth. In puberty, sex steroids are important for the pubertal growth spurt, but importantly, sex steroids also play a role for linear growth in minipuberty. Thus, testosterone levels are high in boys during minipuberty, which may partly explain the higher growth velocity observed in boys compared to girls. Interestingly, the maximum growth velocity difference between boys and girls is observed at 1 month of age, when male testosterone serum levels are at their peak. ${ }^{4748)}$ In addition, boys with congenital hypogonadotropic hypogonadism $(\mathrm{CHH})$, thus lacking the infant testosterone surge, have decreased growth rate during minipuberty compared to controls. ${ }^{49)}$ The hormonal differences between boys and girls during minipuberty appears to be important for sex differences in body composition, with males accumulating more lean mass and ultimately gaining a lower percent fat mass than females. ${ }^{50)}$

\section{Minipuberty in different species}

The transition from one life-history stage to the next is initiated by switch mechanisms such as the rise in hormones during the minipuberty. Evolutionary theories try to explain the variations in these life stages explored both among and within species. Humans differ from other species by being born immature and helpless and having a relatively short period of infancy followed by a long childhood period. ${ }^{51)}$ Previous studies investigated the postnatal hormonal levels in several animal species such as mouse, rat, and horse as well as newborn boys and found a postnatal surge of reproductive hormones of mammals in general, but these studies were limited by the less precise assays for measurement of hormones available at that time. ${ }^{52)}$ However, in other higher primates, minipuberty has been discovered with activation of the pulsatile GnRH release during infancy followed by the quiescent period until the onset of puberty in these species. In vitro studies revealed that embryonic GnRH neurons from rhesus monkeys have a pulsatile secretion and suggested that the pulsatile release of GnRH becomes functional during early fetal development. ${ }^{53)}$ Another study on rhesus monkeys indicated that the switch that turns off the GnRH pulsation during infancy was associated with a decline in the numbers of kisspeptin neurons in the arcuate nucleus in agonadal male monkeys. ${ }^{54)}$ In addition, recent rodent studies revealed that minipuberty also occurs in mice and that gonocyte transformation is influenced by the transient FSH signaling pathway. ${ }^{55)}$ Thus, minipuberty is not limited to the human neonate but is observed in other species. However, humans differ compared to other species in their much longer duration of the childhood period spanning the interval between minipuberty and puberty. The evolutionary role of this long hormonally quiescent period in humans compared to other species remains speculative, but the acquisition of skills to accommodate a complex society before being ready to reproduce appears a plausible explanation.

\section{Minipuberty in various differences of sexual development conditions}

The HPG axis can readily be evaluated in newborns suspected of differences of sexual development (DSD) conditions during minipuberty. A few studies on reproductive hormones in infants with DSD conditions exist.

Infants with $\mathrm{CHH}$ have subnormal FSH, LH, and inhibin B levels in minipuberty. ${ }^{56)}$ The postnatal surge of hormones is absent in boys with $\mathrm{CHH}$, who often present with bilateral cryptorchidism with or without micropenis. Hypospadias rarely occur in $\mathrm{CHH}$ because first trimester placental hCG secretion ensure sufficient androgen production needed for early urethral closure, whereas testicular descent and penile growth are dependent on sufficient testosterone and INSL3 secretion in the second half of pregnancy. ${ }^{29,56)}$

In newborns with cryptorchidism reproductive hormones during minipuberty may be altered. Thus, higher FSH and 
LH levels, and reduced inhibin B and INSL3 have been demonstrated in cryptorchid boys. ${ }^{29)}$ Newborn boys with non-palpable testes remain a diagnostic challenge. Clinically it can be difficult to distinguish between boys with anorchia who do not have functional testicular tissue and boys with bilateral cryptorchidism who have intraabdominal testes. However, serum concentrations of LH, FSH, AMH, inhibin $\mathrm{B}$, and testosterone hormone levels in minipuberty differ between the groups and can, therefore, be used as clinical tool to determine the presence of functional testicular tissue during minipuberty in infant boys. ${ }^{57)}$ Furthermore, an exaggerated biphasic gonadotropin pattern is present in boys with anorchia, with higher levels of FSH and LH as well as undetectable AMH and inhibin B levels during minipuberty compared to healthy boys. ${ }^{57}$

Klinefelter syndrome $(47, X X Y)$ is characterized by primary testicular failure and infertility in adulthood, whereas data on the HPG axis during minipuberty are sparse and contradicting. ${ }^{58-60)}$ However, one recent study including 38 infants and measurement of testosterone by means of liquid chromatography/tandem mass spectrometry showed that the majority of infants presented with a testosterone concentration within the normal range, but the testosterone concentrations in the infants with Klinefelter syndrome were significantly lower as compared with controls. ${ }^{61,62)}$ Despite reduced testosterone, INSL3 and LH concentrations were normal in these infants. In addition, normal inhibin $\mathrm{B}$ and $\mathrm{AMH}$ concentrations were found, but significantly elevated FSH in minipuberty. ${ }^{61,62)}$

Turner syndrome $(45, X)$ is characterized by primary ovarian failure, hypergonadotropic hypogonadism, lack of pubertal development, and infertility. A longitudinal study assessed the HPG axis during infancy in patients with Turner syndrome.

FSH and LH demonstrate biphasic age patterns with peaks at infancy and expected puberty, similar to patterns seen in healthy girls, with no dependence of karyotype. Importantly, gonadotropins were highly elevated in minipuberty compared to healthy girls. ${ }^{63)}$

Children with $X$-linked adrenal hypoplasia congenita caused by NROB1 mutations are characterized by adrenal failure and hypogonadotropic hypogonadism, which is not evident in infancy, as studies have suggested that reproductive hormones are normal during minipuberty. ${ }^{64,65)}$

Prader Willi syndrome (PWS) is caused by a deletion of a section of the paternal derived chromosome 15 , which results in mental retardation, obesity, and hypothalamic dysfunction. At birth cryptorchidism, scrotal hypoplasia, and micropenis are frequently reported. By the time of puberty, many of the boys have hypogonadotropic hypogonadism due to their hypothalamic dysfunction, but some of the boys may have hypergonadotropic hypogonadism due to their cryptorchidism. However, in infant PWS boys, levels of LH, FSH, and testosterone during minipuberty were all within reference ranges of healthy boys. ${ }^{6,67)}$

Infants with $A R$ mutations resulting in complete androgen insensitivity syndrome (AIS) have lowered LH and testosterone levels, and male LH/FSH ratio in minipuberty, ${ }^{27)}$ whereas infants with partial AIS have normal or high LH and testosterone levels ${ }^{68)}$ suggesting some physiological role of androgen signaling in the HPG axis activation during minipuberty.

Infants with aromatase deficiency due to CYP19 mutations which results in a lack of estradiol, present with elevated FSH and LH levels during minipuberty in girls, which may suggest that estrogen feedback on the HPG axis activation in minipuberty is more important in girls compared to boys. ${ }^{69,70)}$

\section{Treatment of hypogonadism in minipuberty}

Minipuberty also represents a "window of opportunity" for treatment in conditions with an impaired HPG axis. Treatment with testosterone is effective with regards to penile growth, and a short course of testosterone treatment of micropenis in otherwise healthy boys is widely accepted. Such treatment during minipuberty is effective and well-tolerated without virilization or disturbances of growth. ${ }^{71,72)}$

Few reports of infants with hypogonadotropic hypogonadism treated with gonadotropins during minipuberty exist. ${ }^{73-76)}$ These indicate that short-term treatment with recombinant FSH and hCG may mimic the physiological minipuberty by stimulating the production of testosterone, inhibin B, and $\mathrm{AMH}$ and potentially stimulating the proliferation of Sertoli cells (for review, see $\left.^{777}\right)$.

\section{Minipuberty - a "window of opportunity"}

Minipuberty may represent a "window of opportunity" to evaluate the HPG axis by measuring the basal hormone concentrations without stimulation tests in infants with suspected of reproductive disorders. We have a unique opportunity to evaluate the spontaneous function of the HPG hormone axis during minipuberty, which is lost hereafter for another 10 years until the HPG axis is reactivated in puberty. It is therefore recommended that serum FSH, LH, and testosterone are measured in minipuberty by reliable and ultrasensitive hormone assays in infants with DSD or suspected of $\mathrm{CHH}^{78)}$

\section{Conflicts of interest}

No potential conflict of interest relevant to this article was reported.

\section{References}

1. Aksglaede L, Sørensen K, Petersen JH, Skakkebaek NE, Juul A. Recent decline in age at breast development: the Copenhagen Puberty Study. Pediatrics 2009;123:e932-9.

2. Sørensen K, Aksglaede L, Petersen JH, Juul A. Recent changes in pubertal timing in healthy Danish boys: associations with body mass index. J Clin Endocrinol Metab 2010;95:263-70.

3. Eckert-Lind C, Busch AS, Petersen JH, Biro FM, Butler 
G, Bräuner EV, et al. Worldwide secular trends in age at pubertal onset assessed by breast development among girls: a systematic review and meta-analysis. JAMA Pediatr 2020;174:e195881.

4. Winter JS. Hypothalamic--pituitary function in the fetus and infant. Clin Endocrinol Metab 1982;11:41-55.

5. Massa G, de Zegher F, Vanderschueren-Lodeweyckx M. Serum levels of immunoreactive inhibin, FSH, and $\mathrm{LH}$ in human infants at preterm and term birth. Biol Neonate 1992;61:150-5.

6. Clements JA, Reyes FI, Winter JS, Faiman C. Studies on human sexual development. III. Fetal pituitary and serum, and amniotic fluid concentrations of LH, CG, and FSH. J Clin Endocrinol Metab 1976;42:9-19.

7. Kaplan SL, Grumbach MM. The ontogenesis of human foetal hormones. II. Luteinizing hormone (LH) and follicle stimulating hormone (FSH). Acta Endocrinol (Copenh) 1976;81:808-29.

8. Forabosco A, Sforza C. Establishment of ovarian reserve: a quantitative morphometric study of the developing human ovary. Fertil Steril 2007;88:675-83.

9. Forest MG, Cathiard AM, Bertrand JA. Evidence of testicular activity in early infancy. J Clin Endocrinol Metab 1973;37:148-51.

10. Winter JS, Faiman C, Hobson WC, Prasad AV, Reyes FI. Pituitary-gonadal relations in infancy. I. Patterns of serum gonadotropin concentrations from birth to four years of age in man and chimpanzee. J Clin Endocrinol Metab 1975;40:545-51.

11. Winter JS, Hughes IA, Reyes FI, Faiman C. Pituitarygonadal relations in infancy: 2. Patterns of serum gonadal steroid concentrations in man from birth to two years of age. J Clin Endocrinol Metab 1976;42:679-86.

12. Andersson AM, Toppari J, Haavisto AM, Petersen JH, Simell $\mathrm{T}$, Simell O, et al. Longitudinal reproductive hormone profiles in infants: peak of inhibin B levels in infant boys exceeds levels in adult men. J Clin Endocrinol Metab 1998;83:675-81.

13. Rey R, Picard JY. Embryology and endocrinology of genital development. Baillieres Clin Endocrinol Metab 1998;12:1733.

14. Lanciotti L, Cofini M, Leonardi A, Penta L, Esposito S. Up-to-date review about minipuberty and overview on hypothalamic-pituitary-gonadal axis activation in fetal and neonatal life. Front Endocrinol (Lausanne) 2018;9:410.

15. Reyes FI, Boroditsky RS, Winter JS, Faiman C. Studies on human sexual development. II. Fetal and maternal serum gonadotropin and sex steroid concentrations. J Clin Endocrinol Metab 1974;38:612-7.

16. Takagi S, Yoshida T, Tsubata K, Ozaki H, Fujii TK, Nomura Y, et al. Sex differences in fetal gonadotropins and androgens. J Steroid Biochem 1977;8:609-20.

17. Lee MM, Donahoe PK. Mullerian inhibiting substance: a gonadal hormone with multiple functions. Endocr Rev 1993; 14:152-64

18. Bowles J, Koopman P. Sex determination in mammalian germ cells: extrinsic versus intrinsic factors. Reproduction 2010;139:943-58

19. Wierman ME, Kiseljak-Vassiliades K, Tobet S. Gonadotropin-releasing hormone $(\mathrm{GnRH})$ neuron migration: initiation, maintenance and cessation as critical steps to ensure normal reproductive function. Front Neuroendocrinol 2011;32:43-52.

20. Moore AM, Coolen LM, Porter DT, Goodman RL, Lehman MN. KNDy cells revisited. Endocrinology 2018;159:321934.

21. Seminara SB, Messager S, Chatzidaki EE, Thresher RR, Acierno JS Jr, Shagoury JK, et al. The GPR54 gene as a regulator of puberty. N Engl J Med 2003;349:1614-27.

22. Topaloglu AK, Tello JA, Kotan LD, Ozbek MN, Yilmaz $\mathrm{MB}$, Erdogan S, et al. Inactivating KISS1 mutation and hypogonadotropic hypogonadism. N Engl J Med 2012;366:629-35.

23. Abreu AP, Dauber A, Macedo DB, Noel SD, Brito VN, Gill JC, et al. Central precocious puberty caused by mutations in the imprinted gene MKRN3. N Engl J Med 2013;368:246775.

24. Busch AS, Hagen CP, Almstrup K, Juul A. Circulating MKRN3 levels decline during puberty in healthy boys. J Clin Endocrinol Metab 2016;101:2588-93.

25. Hagen CP, Sørensen K, Mieritz MG, Johannsen TH, Almstrup K, Juul A. Circulating MKRN3 levels decline prior to pubertal onset and through puberty: a longitudinal study of healthy girls. J Clin Endocrinol Metab 2015;100:1920-6.

26. Sehested A, Juul AA, Andersson AM, Petersen JH, Jensen TK, Müller J, et al. Serum inhibin A and inhibin B in healthy prepubertal, pubertal, and adolescent girls and adult women: relation to age, stage of puberty, menstrual cycle, follicle-stimulating hormone, luteinizing hormone, and estradiol levels. J Clin Endocrinol Metab 2000;85:163440 .

27. Johannsen TH, Main KM, Ljubicic ML, Jensen TK, Andersen HR, Andersen MS, et al. Sex differences in reproductive hormones during mini-puberty in infants with normal and disordered sex development. J Clin Endocrinol Metab 2018;103:3028-37.

28. Aksglaede L, Sørensen K, Boas M, Mouritsen A, Hagen $\mathrm{CP}$, Jensen $\mathrm{RB}$, et al. Changes in anti-Müllerian hormone $(\mathrm{AMH})$ throughout the life span: a population-based study of 1027 healthy males from birth (cord blood) to the age of 69 years. J Clin Endocrinol Metab 2010;95:5357-64.

29. Bay K, Virtanen HE, Hartung S, Ivell R, Main KM, Skakkebaek NE, et al. Insulin-like factor 3 levels in cord blood and serum from children: effects of age, postnatal hypothalamic-pituitary-gonadal axis activation, and cryptorchidism. J Clin Endocrinol Metab 2007;92:4020-7.

30. Codesal J, Regadera J, Nistal M, Regadera-Sejas J, Paniagua R. Involution of human fetal Leydig cells. An immunohistochemical, ultrastructural and quantitative study. J Anat 1990;172:103-14.

31. Cortes D, Müller J, Skakkebaek NE. Proliferation of Sertoli 
cells during development of the human testis assessed by stereological methods. Int J Androl 1987;10:589-96.

32. Chemes HE, Rey RA, Nistal M, Regadera J, Musse M, González-Peramato P, et al. Physiological androgen insensitivity of the fetal, neonatal, and early infantile testis is explained by the ontogeny of the androgen receptor expression in Sertoli cells. J Clin Endocrinol Metab 2008;93:4408-12.

33. Lindhardt Johansen M, Hagen CP, Johannsen TH, Main KM, Picard JY, Jørgensen A, et al. Anti-müllerian hormone and its clinical use in pediatrics with special emphasis on disorders of sex development. Int J Endocrinol 2013;2013:198698.

34. Hagen CP, Aksglaede L, Sørensen K, Main KM, Boas M, Cleemann L, et al. Serum levels of anti-Müllerian hormone as a marker of ovarian function in 926 healthy females from birth to adulthood and in 172 Turner syndrome patients. J Clin Endocrinol Metab 2010;95:5003-10.

35. Freeman EW, Sammel MD, Lin H, Gracia CR. Anti-mullerian hormone as a predictor of time to menopause in late reproductive age women. J Clin Endocrinol Metab 2012;97:1673-80.

36. Karkanaki A, Vosnakis C, Panidis D. The clinical significance of anti-Müllerian hormone evaluation in gynecological endocrinology. Hormones (Athens) 2011;10:95-103.

37. Boas M, Boisen KA, Virtanen HE, Kaleva M, Suomi AM, Schmidt IM, et al. Postnatal penile length and growth rate correlate to serum testosterone levels: a longitudinal study of 1962 normal boys. Eur J Endocrinol 2006;154:125-9.

38. Kuiri-Hänninen T, Seuri R, Tyrväinen E, Turpeinen U, Hämäläinen E, Stenman UH, et al. Increased activity of the hypothalamic-pituitary-testicular axis in infancy results in increased androgen action in premature boys. J Clin Endocrinol Metab 2011;96:98-105.

39. Main KM, Toppari J, Suomi AM, Kaleva M, Chellakooty M, Schmidt IM, et al. Larger testes and higher inhibin B levels in Finnish than in Danish newborn boys. J Clin Endocrinol Metab 2006;91:2732-7.

40. Grinspon RP, Freire AV, Rey RA. Hypogonadism in Pediatric Health: Adult Medicine Concepts Fail. Trends Endocrinol Metab 2019;30:879-90.

41. Kuiri-Hänninen T, Kallio S, Seuri R, Tyrväinen E, Liakka A, Tapanainen J, et al. Postnatal developmental changes in the pituitary-ovarian axis in preterm and term infant girls. J Clin Endocrinol Metab 2011;96:3432-9.

42. Kuiri-Hänninen T, Haanpää M, Turpeinen U, Hämäläinen E, Seuri R, Tyrväinen E, et al. Postnatal ovarian activation has effects in estrogen target tissues in infant girls. J Clin Endocrinol Metab 2013;98:4709-16.

43. Cohen HL, Shapiro MA, Mandel FS, Shapiro ML. Normal ovaries in neonates and infants: a sonographic study of 77 patients 1 day to 24 months old. AJR Am J Roentgenol 1993;160:583-6.

44. Jayasinghe Y, Cha R, Horn-Ommen J, O'Brien P, Simmons PS. Establishment of normative data for the amount of breast tissue present in healthy children up to two years of age. J Pediatr Adolesc Gynecol 2010;23:305-11.

45. Schmidt IM, Chellakooty M, Haavisto AM, Boisen KA, Damgaard IN, Steendahl U, et al. Gender difference in breast tissue size in infancy: correlation with serum estradiol. Pediatr Res 2002;52:682-6.

46. Henriksen LS, Hagen CP, Assens M, Busch AS, Skakkebæk NE, Almstrup K, et al. Genetic variations in FSH action affect sex hormone levels and breast tissue size in infant girls: a pilot study. J Clin Endocrinol Metab 2016;101:31918 .

47. Kiviranta P, Kuiri-Hänninen T, Saari A, Lamidi ML, Dunkel L, Sankilampi U. Transient postnatal gonadal activation and growth velocity in infancy. Pediatrics 2016;138:e20153561.

48. Becker M, Oehler K, Partsch CJ, Ulmen U, Schmutzler R, Cammann $\mathrm{H}$, et al. Hormonal 'minipuberty' influences the somatic development of boys but not of girls up to the age of 6 years. Clin Endocrinol (Oxf) 2015;83:694-701.

49. Varimo T, Hero M, Laitinen EM, Miettinen PJ, Tommiska J, Känsäkoski J, et al. Childhood growth in boys with congenital hypogonadotropic hypogonadism. Pediatr Res 2016;79:705-9.

50. Davis SM, Kaar JL, Ringham BM, Hockett CW, Glueck DH, Dabelea D. Sex differences in infant body composition emerge in the first 5 months of life. J Pediatr Endocrinol Metab 2019;32:1235-9.

51. Hochberg Z. Evolutionary perspective in child growth. Rambam Maimonides Med J 2011;2:e0057.

52. Corbier P, Edwards DA, Roffi J. The neonatal testosterone surge: a comparative study. Arch Int Physiol Biochim Biophys 1992;100:127-31.

53. El Majdoubi M, Sahu A, Plant TM. Changes in hypothalamic gene expression associated with the arrest of pulsatile gonadotropin-releasing hormone release during infancy in the agonadal male rhesus monkey (Macaca mulatta). Endocrinology 2000;141:3273-7.

54. Ramaswamy S, Dwarki K, Ali B, Gibbs RB, Plant TM. The decline in pulsatile $\mathrm{GnRH}$ release, as reflected by circulating LH concentrations, during the infant-juvenile transition in the agonadal male rhesus monkey (Macaca mulatta) is associated with a reduction in kisspeptin content of KNDy neurons of the arcuate nucleus in the hypothalamus. Endocrinology 2013;154:1845-53.

55. Li R, Vannitamby A, Yue SSK, Handelsman D, Hutson J. Mouse minipuberty coincides with gonocyte transformation into spermatogonial stem cells: a model for human minipuberty. Reprod Fertil Dev 2017;29:2430-6.

56. Main KM, Schmidt IM, Skakkebaek NE. A possible role for reproductive hormones in newborn boys: progressive hypogonadism without the postnatal testosterone peak. J Clin Endocrinol Metab 2000;85:4905-7.

57. Jespersen K, Ljubicic ML, Johannsen TH, Christiansen P, Skakkebaek NE, Juul A. Distinguishing between hidden testes and anorchia: the role of endocrine evaluation in infancy and childhood. Eur J Endocrinol 2020;183:107-17.

58. Lahlou N, Fennoy I, Carel JC, Roger M. Inhibin B and anti- 
Müllerian hormone, but not testosterone levels, are normal in infants with nonmosaic Klinefelter syndrome. J Clin Endocrinol Metab 2004;89:1864-8.

59. Ross JL, Samango-Sprouse C, Lahlou N, Kowal K, Elder FF, Zinn A. Early androgen deficiency in infants and young boys with 47,XXY Klinefelter syndrome. Horm Res 2005;64:39-45.

60. Aksglaede L, Petersen JH, Main KM, Skakkebaek NE, Juul A. High normal testosterone levels in infants with non-mosaic Klinefelter's syndrome. Eur J Endocrinol 2007;157:345-50.

61. Cabrol S, Ross JL, Fennoy I, Bouvattier C, Roger M, Lahlou $\mathrm{N}$. Assessment of Leydig and Sertoli cell functions in infants with nonmosaic Klinefelter syndrome: insulin-like peptide 3 levels are normal and positively correlated with LH levels. J Clin Endocrinol Metab 2011;96:E746-53.

62. Lahlou N, Fennoy I, Ross JL, Bouvattier C, Roger M. Clinical and hormonal status of infants with nonmosaic XXY karyotype. Acta Paediatr 2011;100:824-9.

63. Hagen CP, Main KM, Kjaergaard S, Juul A. FSH, LH, inhibin $B$ and estradiol levels in Turner syndrome depend on age and karyotype: longitudinal study of 70 Turner girls with or without spontaneous puberty. Hum Reprod 2010;25:313441.

64. Kaiserman KB, Nakamoto JM, Geffner ME, McCabe ER. Minipuberty of infancy and adolescent pubertal function in adrenal hypoplasia congenita. J Pediatr 1998;133:300-2.

65. Galeotti C, Lahlou Z, Goullon D, Sarda-Thibault H, CahenVarsaux J, Bignon-Topalovic J, et al. Longitudinal evaluation of the hypothalamic-pituitary-testicular function in 8 boys with adrenal hypoplasia congenita (AHC) due to NR0B1 mutations. PLoS One 2012;7:e39828.

66. Fillion M, Deal CL, Van Vliet G. Normal minipuberty of infancy in boys with Prader-Willi syndrome. J Pediatr 2006;149:874-6.

67. Hirsch HJ, Eldar-Geva T, Erlichman M, Pollak Y, Gross-Tsur V. Characterization of minipuberty in infants with PraderWilli syndrome. Horm Res Paediatr 2014;82:230-7.

68. Bouvattier C, Carel JC, Lecointre C, David A, Sultan C, Bertrand AM, et al. Postnatal changes of T, LH, and FSH in 46,XY infants with mutations in the AR gene. J Clin Endocrinol Metab 2002;87:29-32.

69. Belgorosky A, Pepe C, Marino R, Guercio G, Saraco N, Vaiani E, et al. Hypothalamic-pituitary-ovarian axis during infancy, early and late prepuberty in an aromatase-deficient girl who is a compound heterocygote for two new point mutations of the CYP19 gene. J Clin Endocrinol Metab 2003;88:5127-31.

70. Deladoëy J, Flück C, Bex M, Yoshimura N, Harada N, Mullis PE. Aromatase deficiency caused by a novel P450arom gene mutation: impact of absent estrogen production on serum gonadotropin concentration in a boy. J Clin Endocrinol Metab 1999;84:4050-4.

71. Hatipoğlu N, Kurtoğlu S. Micropenis: etiology, diagnosis and treatment approaches. J Clin Res Pediatr Endocrinol 2013;5:217-23.

72. Bin-Abbas B, Conte FA, Grumbach MM, Kaplan SL. Congenital hypogonadotropic hypogonadism and micropenis: effect of testosterone treatment on adult penile size why sex reversal is not indicated. J Pediatr 1999;134:579-83.

73. Main KM, Schmidt IM, Toppari J, Skakkebaek NE. Early postnatal treatment of hypogonadotropic hypogonadism with recombinant human FSH and LH. Eur J Endocrinol 2002;146:75-9.

74. Bougnères P, François M, Pantalone L, Rodrigue D, Bouvattier C, Demesteere E, et al. Effects of an early postnatal treatment of hypogonadotropic hypogonadism with a continuous subcutaneous infusion of recombinant follicle-stimulating hormone and luteinizing hormone. J Clin Endocrinol Metab 2008;93:2202-5.

75. Stoupa A, Samara-Boustani D, Flechtner I, Pinto G, Jourdon I, González-Briceño L, et al. Efficacy and safety of continuous subcutaneous infusion of recombinant human gonadotropins for congenital micropenis during early infancy. Horm Res Paediatr 2017;87:103-10.

76. Kohva E, Huopio H, Hietamäki J, Hero M, Miettinen PJ, Raivio T. Treatment of gonadotropin deficiency during the first year of life: long-term observation and outcome in five boys. Hum Reprod 2019;34:863-71.

77. Swee DS, Quinton R. Congenital hypogonadotrophic hypogonadism: minipuberty and the case for neonatal diagnosis. Front Endocrinol (Lausanne) 2019;10:97.

78. Quinton R, Mamoojee Y, Jayasena CN, Young J, Howard S, Dunkel L, et al. Society for Endocrinology UK guidance on the evaluation of suspected disorders of sexual development: emphasizing the opportunity to predict adolescent pubertal failure through a neonatal diagnosis of absent minipuberty. Clin Endocrinol (Oxf) 2017;86:305-6. 